\title{
An Unusual Anatomic Variation of Dorsal Sensory Branches of the Ulnar Nerve: A Case Report
}

\author{
Ulnar Sinirin Dorsal Duysal Dallarının Alıșılmadık bir Anatomik Varyasyonu: Bir Olgu Sunumu
}

\section{Mehmet Bülent Özdemir', Ramazan Hakan Özcan², Dilek Bağdatlı², Șahika Pınar Akyer1', Gökșin Nilüfer Yonguç ${ }^{1}$}

${ }^{1}$ Department of Anatomy, Pamukkale University, Denizli, Turkey, ${ }^{2}$ Department of Plastic and Reconstructive Surgery, Pamukeale University, Denizli, Turkey

\begin{abstract}
In some instances, it is mandatory to know the anatomy of the dorsal sensory branches of the ulnar nerve. The dorsal sensory branches consist of the area of most dense innervations with their anatomical variants. These variations are very important in the surgical and medical procedures dealing with the area. In this paper, we present a case of an unusual variation of the dorsal cutaneous ulnar nerve. The variation was observed in the operation of a right forearm of a 43 year old male following a traffic accident injury. Dorsal cutaneous Ulnar nerve was observed in an unusual course. It was piercing the flexor carpi ulnaris muscle's tendon and then going into the skin superficially. To our knowledge, this type of variation has never been published before. The knowledge of this type of variation may be useful during surgeries and electrophysiological examinations of the area.
\end{abstract}

Key words: anatomy, ulnar nerve, forearm, flexor carpi ulnaris muscle, peripheral nerves

\section{ÖZET}

Ulnar sinirin dorsal duysal dallarının anatomisini bilmek bazı durumlarda zorunludur. Dorsal duysal dallar, anatomik varyasyonları olan en yoğun innervasyon alanını içerir. Bu bölgeyle ilgili medical ve cerrahi ișlemler için bu varyasyonlar çok önemlidir. Bu yazıda dorsal kutanöz ulnar sinirin bilinmeyen bir varyasyonunu sunuyoruz. Varyasyon trafik kazası sonrası ameliyat olan 43 yașındaki bir erkeğin sağ kolunda görüldü. Dorsal kutanöz ulnar sinir normalden farklı ir seyirde izlendi. Sinir önce flexor carpi ulnaris kasını deliyor, daha sonra da cilde doğru yüzeyselleșiyordu. Bizim bildiğimize göre, bu tür bir varyasyon daha önce hiç yayınlanmamıștı. Böyle bir varyasyonun bilinmesi bölgenin cerrahisi ve elektrofizyolojik çalıșmaları sırasında yararlı olabilir.

Anahtar kelimeler: anatomi, ulnar sinir, önkol, flexor carpi ulnaris kası, periferik sinirler

Mehmet Bülent Özdemir, Pamukekale Üniversitesi T⿰р Fakültesi, Anatomi Anabilim Dal, Deniali, Türkive, Tel. 05427253674

Email.mehmeto@pau.edu.tr

Gelis Taribi: 11.05.2011 • Kabul Taribi: 28.07.2011
Dorsal cutaneous nerve of the hand or DCU is one of the terminal branches of the ulnar nerve ${ }^{1,2}$. Ulnar nerve fibers derive from the eighth cervical and first thoracic roots in the majority of cases, however it may arise solely from the eighth cervical or from seventh and eighth cervical roots ${ }^{1}$. Nerve fibres pass to the medial cord of brachial plexus and are individualized as ulnar nerve in the axilla. In the upper arm, the ulnar nerve is in relation to major vessels and gives branches only at the proximal forearm ${ }^{1,2}$.

The DCU leaves the main ulnar nerve at about the midpoint of the medial and distal thirds of the fore$\operatorname{arm}^{1,2}$. Like the main ulnar nerve, DCU is between the ulnar bone and the flexor carpi ulnaris muscle, and covered by its muscular portion. At the level of its tendon, DCU is situated dorsally and medially. DCU leaves the ulnar nerve, piercing the antebrachial fascia, at the level of 4,8 to $10 \mathrm{~cm}$ above the ulnar styloid process or at a mean distance of $8,3 \mathrm{~cm}$ $(\mathrm{SD}=2,4)$ from the proximal border of the pisiform bone $^{3}$, taking a posterior direction. DCU then courses around the ulnar styloid process medially and dorsally, and at the fifth metacarpal joint (located 2 or $3 \mathrm{~cm}$ distally to the ulnar styloid process), it gives off two ${ }^{1}$ or three ${ }^{1,2,4}$ main branches.

In this paper, we present a case of an unusual variation of the dorsal cutaneous ulnar nerve.

\section{Case}

An unusual course of DCU was observed in a 43 year old male patient's right forearm operation. The right forearm was injured in a traffic accident. There was an open bone fracture on articulatio cubiti. The 


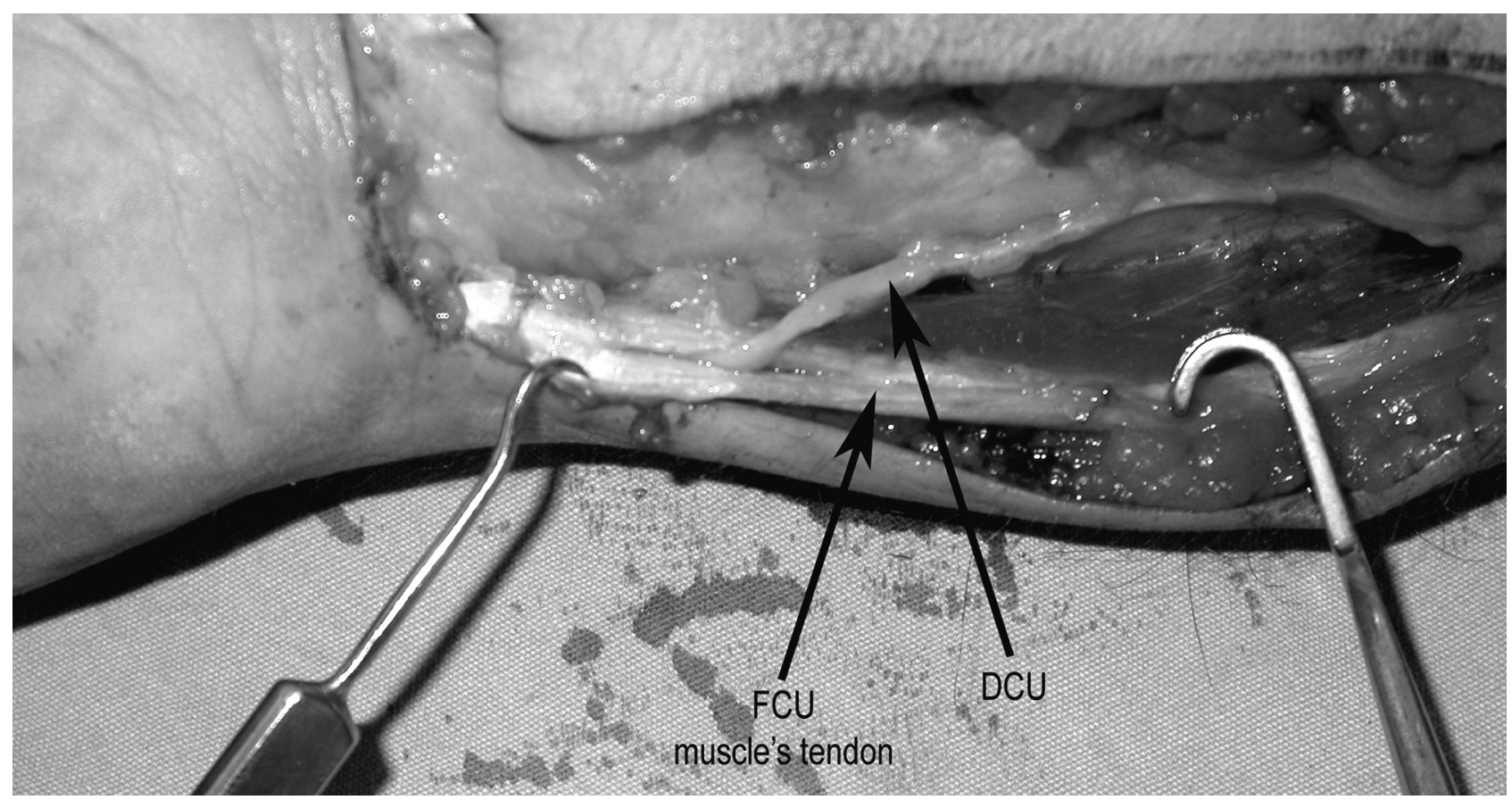

Figure 1. The dorsal cutaneous branch of Ulnar nerve was leaving the main ulnar nerve at the midpoint between the medial and distal thirds of the forearm. It was positioned between the ulnar bone and the flexor carpi ulnaris muscle.

median and the ulnar nerves, brachial artery and the tendons of the muscles were cut. The loose connective tissue surrounding the injured area had also deformities.

A plastic and reconstructive surgeon operated the patient. During the course of the surgery while transferring the flexor carpi ulnaris muscle, the operator noticed that the DCU was piercing the tendon of the flexor carpi ulnaris muscle. The DCU was leaving the main ulnar nerve at the midpoint between the medial and distal thirds of the forearm. It was positioned between the ulnar bone and the flexor carpi ulnaris muscle. After piercing the tendon, the DCU was following its normal anatomic course (Figure 1 and 2). In the MR imaging examination of left forearm, we could not demonstrate a similar variation.

\section{Discussion}

Intraneural topography of the fibres detailed to various branches of the ulnar nerve was first studied by Sunderland ${ }^{1}$. He could trace DCU fibres beginning from several centimetres above the humeral epicondylar line to two centimetres below the ulnar styloid process. He observed a relatively precise localization of DCU fibres in the ulnar trunk, emphasizing their long independent intraneural course just to turn into

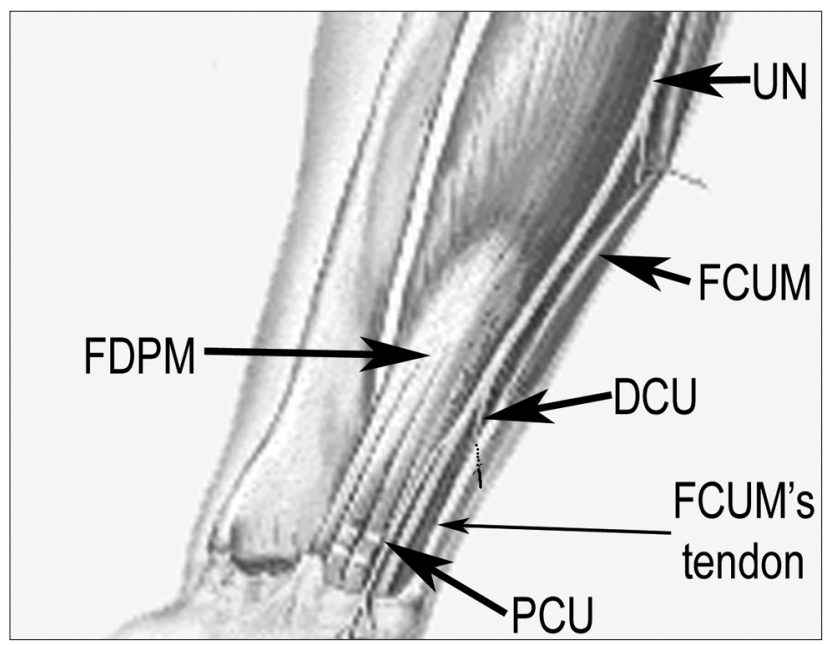

Figure 2. Schematic representation of the variation.

a terminal ramus. Jabaley et $a .^{2}$ had the same experience in their own dissections. They concluded that "DCU and ulnar nerve are two separate nerves travelling within a common epineural conduit while still retaining their autonomy". The DCU leaves the main ulnar nerve at about the midpoint between the medial and distal thirds of the forearm, according to classical textbooks ${ }^{1,2}$. Rarely, the DCU may leave the ulnar trunk just below the medial humeral epicondyle ${ }^{1}$. 
Like the main ulnar nerve, DCU is between the ulnar bone and the flexor carpi ulnaris muscle, covered by its muscular portion. At the level of its tendon origin, DCU is situated dorsally and medially.

DCU leaves the ulnar nerve by piercing the antebrachial fascia at the level of 4,8 to $10 \mathrm{~cm}$ above the ulnar styloid process ${ }^{1,2}$ or at an average distance of $8,3 \mathrm{~cm}(\mathrm{SD}=2,4)$ away from the proximal border of the pisiform bone, in the posterior direction. These measured distances are important references for placing stimulating electrodes. DCU, then courses around the ulnar styloid process medially and dorsally, and at the fifth metacarpal joint $2 \mathrm{~cm}$ or $3 \mathrm{~cm}$ distally to the ulnar styloid process, it gives off two ${ }^{1}$ or three ${ }^{1}$, ${ }^{2,4}$ main branches.

Alexandre and Martinon dissected thirty hands and found both types of branching in a proportion of $2: 1$, respectively for two and three branches. The hands with two main branches as lateral and medial have a secondary division in the lateral ramus ${ }^{1}$. These data help to define the location of the recording electrodes. The active electrode may be positioned either along the fifth metacarpal bone or between the fourth and the fifth metacarpals and the reference electrode is placed $3 \mathrm{~cm}$ distally.

The dorsum of the hand may be innervated entirely by the superficial radial nerve as in the case of DCU agenesis. A DCU was also absent in one of the dissected upper extremities ${ }^{3}$. Alternatively the posterior or the lateral cutaneous nerves of the forearm may extend further distally than usual, modifying the standard pattern of innervation. Variability in dorsal hand innervation may be caused also by communicating branches of ulnar-radial or ulnar-ulnar. A DCU giving a radial branch in the dorsum of the hand is less frequent $(10 \%)$ than the radial nerve giving branch to DCU $(77 \%)^{1}$. Anastomosis between the superficial radial nerve and DCU was found in $4-15 \%$ of the hands ${ }^{5}$. Complete absence of anastomosis is also possible, as shown in $13 \%$ of the anatomical specimens ${ }^{1}$.

The anatomical variants mentioned above may be responsible for low amplitude or absence of response observed in the conduction velocity test, thus predisposing to incorrect physiological test results and diagnosis $^{6}$. A paired conduction velocity examination between the DCU and the superficial radial nerve should help in avoiding misinterpretation.
Kaplan ${ }^{1}$ described a peculiar pattern of branching of the DCU proximal to its division in the dorsum of the hand and distal to its joining with the volar sensory branch of the ulnar nerve. As the pisiform bone and the tendon insertion site of the flexor carpi ulnaris are very close to this anastomosis, a neural injury may occur in case of pisiform bone fractures and during the surgical procedures of the area. Sunderland ${ }^{1}$ had noted a similar anatomical anastomosis.

In $2 \%$ of the hands studied anatomically by Bonnel and $\mathrm{Vila}^{7}$ there was a communication between the DCU and the ulnar proper palmar digital nerve of the fifth finger. This anomalous branch of the DCU has been designated as Kaplan's anastomosis and it may join with the superficial or the deep rami of the ulnar nerve. In $4 \%$ of the hands, Kaplan's anastomosis left the DCU medially at about 2,5 centimetres proximal to the ulnar styloid process and provided innervation to the radiocarpal joint, the abductor digiti minimi muscle, and the fifth carpometacarpal joint $^{8}$. Examination of the conduction velocity of the DCU may provide good complementary information in the electroneuromyographic analysis of the ulnar nerve palsies. In addition, patients may express symptoms and signs in the DCU territory, associated with more widespread peripheral neuropathy as in mononeuropathy multiplex or polyneuropathies?.

In conclusion, to our knowledge our case was unique. This type of variation has never been published before. The knowledge of this type of variation may be useful during surgeries and electrophysiological examinations of the area.

\section{References}

1. Garibaldi SG, Nucci A. Dorsal cutaneous branch of ulnar nerve: an appraisal on the anatomy, injuries and application of conduction velocity studies in diagnosis. Arq Neuropsiquiatr 2000; 58: 637-41.

2. Jabaley ME, Wallace WH, Heckler FR. Internal topography of major nerves of the forearm and hand: a current view. J Hand Surg 1980; 5:1-18.

3. Botte MJ, Cohen MS, Lavernia CJ, et al. The dorsal branch of the ulnar nerve: an anatomic study. J Hand Surg 1990; 5: 6037.

4. Greene TL, Steichen JB. Digital nerve grafting using the dorsal sensory branch of the ulnar nerve. J Hand Surg 1985; 10: $37-40$. 
5. Auerbach DM, Collins ED, Kunkle KL, et al. The radial sensory nerve: an anatomic study. Clin Orthop Rel Res 1994; 308: 241-9.

6. Beattie JR, Ross MA. Electrophysiologic assessment of the dorsal ulnar cutaneous nerve reveals anatomic variation (medial location) is common. Muscle Nerve 1993; 16: 1094.

7. Bonnel F, Vila RM. Anatomical study of the ulnar nerve in the hand. J Hand Surg 1985; 10:165-8.

8. Hoogbergen MM, Kauer JMG. An unusual ulnar nerve median nerve communicating branch. J Anat 1992; 181: 513-6.

9. Chimelli L, Freitas M, Nascimento O. Value of nerve biopsy in the diagnosis and follow up of leprosy: the role of vascular lesions and usefulness of nerve studies in the detection of persistent bacilli. J Neurol 1997; 244: 318-23. 